\title{
Study of antiviral activity of a new plant origin preparation neoflazidum on a model of the hepatitis c virus
}

\author{
Yu. I. Porva ${ }^{1}$, S. L. Rybalko'1, L. I. Palchykovs'ka², V. P. Atamanyuk \\ ${ }^{1}$ Gromashevsky L. V. Institute of Epidemiology and Infection Diseases, NAMS of Ukraine \\ 5, Amosova Str., Kyiv, Ukraine, 03038 \\ ${ }^{2}$ Institute of Molecular Biology and Genetics, NAS of Ukraine \\ 150, Akademika Zabolotnoho Str., Kyiv, Ukraine, 03680 \\ epidemics@ukr.net L.Palchykovska@ukr.net
}

\begin{abstract}
This paper presents some results concerning investigation of antiviral activity of a new plant origin preparation - neoflazidum, a form of proteflazidum - using a model of hepatitis C virus-producing Jurkat cell culture $\left(\right.$ Jurkat $\left.^{H C V}\right)$ which has been previously transfected with complementary DNA preparations isolated from different types of hepatitis $\mathrm{C}$ virus (HCV). To obtain these preparations, HCV RNA preparations were isolated from viral material of HCV-diseased patients, the transfecting agent Turbofect being used. The cytotoxic dose $\left(\mathrm{CD}_{50}\right)$ was shown to be $37.2 \mu \mathrm{g} / \mathrm{ml}$, the effective dose $\left(\mathrm{ED}_{50}\right)$ being $0.46 \mu \mathrm{g} / \mathrm{ml}$ for the HCV type $3 \mathrm{a}$; this dose, however, was as high as $3.7 \mu \mathrm{g} / \mathrm{ml}$ when neoflazidum had been tested for HCV type $1 \mathrm{~b}$. Therefore, the selectivity index for the HCV type 3a reached 80.8 in the Jurkat ${ }^{H C V-3 a}$ cell system, being as low as 10.0 for the HCV type $1 \mathrm{~b}$. Using a model system RNAP T7, the antiviral neoflazidum activity was demonstrated to be realized due to interferons $\alpha$ - and $\gamma$-induction and RNA synthesis inhibition.
\end{abstract}

Keyword s: antiviral activity, neoflazidum, hepatitis $\mathrm{C}$ virus, transfecting, interferons $\alpha$ - and $\gamma$-induction, model system RNAP T7

\section{Introduction}

The victims of the hepatitis $\mathrm{C}$ virus (HCV) are about 130-170 million people worldwide, i.e. about 2.2$3.0 \%$ of all our planet population, 3-4 million becoming infected every year[1]. In $55-85 \%$ of all cases the infection becomes chronic, leading usually to serious liver damages. During the last 20 years the chronic hepatitis $\mathrm{C}$ causes the liver cirrhosis in about $4-20 \%$ of the patients. The patients with identified cirrhosis are known to have a frequent risk of liver decompensation (18-29\%) during next 10-20 years and a risk of the hepatocellular carcinoma development (10-30 \%) during next 20 years. Nowadays, the chronic hepatitis $\mathrm{C}$ patients are usually treated with the pegylated interferon preparations (Peg-IFN) combined with rybavirin (RBV). Such a combination permits to reach the permanent absence of $\mathrm{HCV}$ RNA (i.e. steadfast virological response, SVR) in $40-52 \%$ of the patients with chronic hepatitis C caused by the genotype 1 [2-4].

According to the last estimations concerning the HCV-caused mortality, 50 thousand patients worldwide die directly as hepatitis victims, and 300 thousand persons perish due to the HCV-caused liver malignancies, 800 thousand persons being killed by cirrhosis; these levels are thought to become higher [5].

There are several $\mathrm{HCV}$ genotypes, the genotype 1 is thought to be the most spread in the world. This virus genotype is found in more than $70 \%$ of the chronic HCV patients in Europe and the USA; it is

(C) 2015 Yu. I. Porva et al.; Published by the Institute of Molecular Biology and Genetics, NAS of Ukraine on behalf of Biopolymers and Cell. This is an Open Access article distributed under the terms of the Creative Commons Attribution License (http://creativecommons.org/licenses/by/4.0/), which permits unrestricted reuse, distribution, and reproduction in any medium, provided the original work is properly cited 
not only the most spread, but is also the most treatment-resistant to the up-to-date standard Peg-IFN/ RBV therapy. In almost $50 \%$ of the persons with chronic hepatitis due to the HCV genotype $1 \mathrm{~b}$, the Peg-IFN/RBV therapy leads to the SVR; in 24 weeks following the end of the treatment it becomes impossible to evaluate the level of viral RNA. The SVR is a generally accepted treatment index [6].

There are no effective therapeutic approaches for the patients who have not reached the SVR after the standard treatment. It was reported that the refresher courses of Peg-IFN/RBV treatment of the chronic patients infected by the HCV type $1 \mathrm{~b}$ led to the SVR in $4-21 \%$ of the previously non-responder patients as well as in $23-31 \%$ of relapsing ones. Thus, we do need more effective therapy approaches with a shorter duration of the treatment course.

Telaprevir is a powerful, reverse, selective, linear peptidomimetic inhibitor of the HCV-specific serine protease NS3-4A; it is an additional antiviral drug used together with Peg-IFN/RBV. In the chronic patients infected by the HCV genotype $1 \mathrm{~b}$ the telaprevir use combined with the Peg-IFN/ RBV during 24 to 48 weeks, is significantly accompanied by a higher SVR frequency comparing to 48-week-long PegIFN/RBV therapy only. The increased therapy efficacy was found in both the patients having not been previously treated and the patients after previous unsuccessful therapy with non-decreased virus level as well as in a lot of different patients including the persons with continuously low SVR following standard Peg-IFN/ RBV approach [7-9].

Nowadays there are promising antiviral preparations of plant origin. Plants and plant extracts had been traditionally used during centuries long before different active products were isolated as a result of science and technology progress. The WHO specialists calculated that about $80 \%$ of the world population still use traditional medicine approaches for the infectious diseases therapy [10].

Natural flavonoids of plant origin are known since 1940; however, the problems concerning the study of their antiviral activities became actual only 25 years ago. In the late 1990s, pharmaceutical compa- nies took interest in these compounds and initiated preclinical studies and clinical trials of flavonoidbased preparations. Some compounds with promising raw material bases, such as, for example, quercitin and dehydroquercitin, are now investigated on the largest scale $[11,12]$.

Flavonoids are, however, labile unstable compounds, their production being accompanied by certain technological difficulties. Organic synthesis and/or modification of substances of easy production are among the most important approaches permitting to obtain highly effective flavonoids of specific formulations and specifically directed action. An example of such successful design of medicinal substance is the obtaining of the synthetic drug 6,4-dichlorflavan [13]. However, a lot of synthetic medications possessing a high antiviral activity in vitro, during clinical trials were shown to be significantly less effective. That is why numerous intensive investigations are now carried out in this field.

A research group of Iry Jacobson (Cornwell University) studied the sofosbuvir therapeutic effect in combination with ribovirin for the therapy of patients with chronic hepatitides infected with the HCV types 2 and 3, the standard therapy being futile. The use of this new drug combination permitted to obtain the SVR (no virus RNA was found in blood) in $78 \%$ of patients in 3-4 months of treatment.

Another specialists' group led by E.Lavitz (Texas State University) studied sofosbuvir, ribavirin, and pegylated alpha-2a interferon combinations for the therapy of previously non-treated patients with chronic hepatitis caused by all HCV subtypes including the most spread genotype $1 \mathrm{HCV}$. In three months of treatment the SVR was reached in 90 genotype 1-infected patients. No serious side effects were seen in both cases. Sofosbuvir belongs to the RNA-polymerase inhibitor class oppressing the HCV reproduction [14].

It goes without saying that the researches concerning the inhibition efficacy of the hepatitis $\mathrm{C}$ virus reproduction do need an experimental model of infection; numerous attempts aiming to obtain 
such a model were unsuccessful during a very long time, the HCV replication levels in vitro being extremely low.

There are publications showing that the transformed human hepatome cells Huh-7 carrying a luceferase reporter construction (pGL3) is an up-todate cell model for the HCV reproduction. Other standard models used by foreign researchers are MT-4 and Daudi cells as well as HeLa cells transformed by a recombinant plasmid (with the $\mathrm{pBK}$ CMC-HCV-replicon) containing structural $\mathrm{HCV}$ genes [15].

The HCV reproduction in cell cultures is not a stable process, the virus kept at $70{ }^{\circ} \mathrm{C}$, looses its infectivity. To maintain this virus, we used complementary HCV DNA, the virus having been isolated from the hepatitis $\mathrm{C}$ patient. The transfection of MT-4 and RHNN cell lines by complementary DNA (cDNA) preparations permitted to obtain the HCVproducing cell cultures [16].

The aims of this paper were to obtain the HCVproducing cDNA-transfected Jurkat cells and to study the anti-HCV activity and the mechanism of neoflazidum action.

\section{Materials and Methods}

\section{Preparations:}

\section{Neoflazidum}

It is a mixture of flavonoids obtained from wild natural flavonoid-rich gramineous plants - Calamagrostis epigeios L. and Deschampsia caespitosa L. The concentration obtained is $3.72 \mathrm{mg} / \mathrm{ml}$.

PolyI-polyC, reference interferon inducer (Calbiochem, USA).

\section{Cell cultures:}

L929. Murine established cell line was received from the collection of Cell Culture Museum of the D.I.Ivanovski Institute of Virology (RAMS, RF). These cells grow at $37^{\circ} \mathrm{C}$ in the RPMI-1640 (SigmaAldrich, USA) medium supplemented with heated fetal serum (12\%), the cell density being (15-20) $\mathrm{x} 10^{4}$ cells $/ \mathrm{ml}$.
Jurkat. The established cell line of human origin was obtained from a patient with T-lymphoblastoid leukemia at the Institute of Immunology (RAMS, RF. These cells grow in suspension at $37^{\circ} \mathrm{C}$ in the RPMI-1640 medium supplemented with $2 \%$ glutamine and $10 \%$ heated fetal serum, the $\mathrm{CO}_{2}$ concentration in the thermostat air being $5 \%$. The cell density is usually (3-9) $\times 10^{5}$ cells $/ \mathrm{ml}$.

$R H N N$. The established cell line, epithelioid monolayer-forming culture obtained from a rat Heiser node neurinoma was induced by transplacental injection of ethylnitrozourea $[17,18]$. It grows in the EMEM medium supplemented with $10-20 \%$ of calf embryo serum, received from the Human Morphology Research Institute (RAMS, RF).

\section{Virus preparations:}

The vesicular stomatitis virus (VSV) of the Indiana strain was received from the Museum of Viruses of the D.I.Ivanovski Institute of Virology (RAMS, RF), it infectious titer in cultured cells L41 reaching 4.0 $5.0 \mathrm{lg} \mathrm{TCID}_{50} / \mathrm{ml}$.

\section{Animals:}

White non-inbred mice (14-18 g) were grown in standard conditions in the vivarium of the state enterprise "Lev Gromashevski Institute of Epidemiology \& Infectious diseases, Academy of Medical Sciences of Ukraine".

\section{Model cultures:}

HCV-producing cells Jurkat, splitting suspension cultures of lymphoblastoid origin, transfected by different types of this virus.

As the HCV source, the non-diluted blood plasma samples of HCV-infected persons were used with different virus load; such plasma contains $\mathrm{HCV}$ RNA. All viral RNA preparations were isolated using a kit "RIBO-sorb" (RF). The HCV complementary DNA (cDNA) was synthesized by the reverse transcription reaction using a kit «Reverta-L» $(\mathrm{RF})$. $10 \mu \mathrm{l}$ of RNA samples were added to $10 \mu \mathrm{l}$ of prepared reaction mixture (lyophilized plant preparation, $125 \mu \mathrm{l}$ of the RT-mix solution and $6 \mu \mathrm{l}$ of the 
murine leukemia virus (MMLv) revertase; the transcription was carried out at $37^{\circ} \mathrm{C}$ during $30 \mathrm{~min}$, and cDNA was obtained.

\section{Transfection process using the Turbofect}

Cell cultures Jurkat grown in suspension were transfected using a transfecting reagent Turbofect. The transfection was carried out according to the standard protocol using Turbofect (Thermo Scientific, Lithuania). To realize a transfection process, the cell density is to reach $5 \times 10^{4}$ (for established line cells) and $5 \times 10^{5}$ (for cells grown in suspension) per $1 \mathrm{ml}$ of nutrient medium. A cDNA preparation $(1 \mu \mathrm{g})$ was diluted in $100 \mu$ of serum-free RPMI-1640 medium, the tracfecting reagent being added during stirring (by aid of a pipette or a vortex). Following pipetting or stirring in the vortex, the sample was incubated at room temperature $(15-20 \mathrm{~min})$. Then $100 \mu \mathrm{l}$ of a mixture of DNA and transfecting reagent were dropped into each cell culture-containing well and incubated in a $\mathrm{CO}_{2}$-thermostat at $37^{\circ} \mathrm{C}$. The virus detection was carried out using the PCR approach on the second passage ( $9^{\text {th }}$ day of cultivation) and on the fifth one (17 $7^{\text {th }}$ day of cultivation). All the cDNAtransfected Jurkat cultures produced the HCV both on the $9^{\text {th }}$ and $17^{\text {th }}$ day of cultivation.

\section{Measurement of HCV load in clinical samples}

Quantitative estimation of the HCV RNA in clinical samples was carried out using the real-time PCR with hybridization and fluorescent detection. For this aim, a reagent kit "AmpliSense HCV-MonitorFRT" (Russia) and an apparatus "Rotor-Gene 3000/6000" (“Corbett Research”, Australia) were used.

\section{In vitro transcription reaction.}

The effect of the preparation investigated on the RNA synthesis was evaluated in the transcription system RNAP T7 using available reagents of the firma «Fermentas» (Lithuania). The transcription was carried out using $20 \mu \mathrm{l}$ of reaction mixture containing $0.5 \mu \mathrm{g}$ of linearized DNA of the plasmid $p T Z 19 R$ carrying the RNAP T7, ribonucleoside tri- phosphates, concentration of each one being $2 \mathrm{mM}$, 20 active units of the RNAse inhibitor RiboLock ${ }^{\mathrm{TM}}$, $40 \mathrm{mM}$ Tris- $\mathrm{HCl}, \mathrm{pH} 7.9,6 \mathrm{mM} \mathrm{MgCl}, 2$ mM spermidine, $10 \mathrm{mM} \mathrm{NaCl}, 10 \mathrm{mM}$ dithiotreiitol (DTT), and 12 active units of the T7 RNA-polymerase. These substances were solved in DMSO $(1 \mathrm{mg} / \mathrm{ml})$. The DMSO concentration in control and test samples $(2.5 \%)$ has no influence on the level of the RNA synthesis. The reaction mixture was kept at $37{ }^{\circ} \mathrm{C}$ during $45 \mathrm{~min}$, the reaction being stopped by cooling (up to $-20^{\circ} \mathrm{C}$ ). The reaction products obtained were detected by gel electrophoresis in $1 \%$ agarose supplemented with ethidium bromide $(0.3 \mu \mathrm{g} / \mathrm{ml})$. The RNA transcripts were visualized using a UV-transilluminator. The intensity of RNA bands on photos were measured by a densitometry method using the program Scion Image. The $\mathrm{IC}_{50}$ value (inhibitor concentration necessary for a decrease of the enzyme activity by $50 \%$ ) was calculated from the plot describing the dependence of activity on the enzyme concentration.

\section{Therapeutic neoflazidum activity against the $\mathrm{HCV}$}

To study the antiviral activity, the preparation of different concentrations was put intothe $\mathrm{HCV}$-producing Jurkat cultures, the virus level being evaluated for each sample in 5 days using the PCR.

\section{Neoflazidum IFN-inductive activity in vivo}

The IFN-inducing activity of the preparation in vivo was studied on non-inbred white mice, their mass being $14-18 \mathrm{~g}$. The preparation was injected intraperitoneally. In $24 \mathrm{~h}$ the mice were killed by euthanasia; the IFN activities were determined in murine blood sera and in different animal organs according to a generally accepted approach - the CPE inhibition being caused by the vesicular stomatitis virus in L929 cell cultures [20].

\section{Data analysis}

All experiments were performed in triplicates. The antiviral activity of the neoflazidum was expressed as the $\log _{10}$ reduction of the viral titer by comparison 
Study of antiviral activity of a new plant origin preparation neoflazidum on a model of the hepatitis c virus

with untreated controls (inhibition of infectious titer). The standard deviation in the reduction of virus titer was about $0.5 \log _{10}$. The neoflazidum was considered active only when the virus yield decreases $\geq 2 \log _{10}$, at the effective dose $\mathrm{ED}_{50}$.

\section{Results and Discussion}

To obtain the HCV-producing cell culture, the HCV RNA preparation was isolated; the HCV-RNA complementary DNA preparation was used for the Jurkat cultures transfection followed by the PCR analysis (Table 1).

With the transfecting reagent Turbofect the HCV cDNA-transfected Jurkat cell cultures with stable HCV production (JurkatHCV) have been originated. The viral load in all variants of the HCVtransfected cells progressively increased with the passages of the culture. In the cells transfected with the HCV 1 b subtype, the viral load was the highest and exceeded three-fold that in the cells transfected with the HCV 3 a subtype. Taking into account that $\mathrm{HCV} 1 \mathrm{~b}$ and $3 \mathrm{a}$ are the most prevalent in Ukraine, JurkatHCV-3a and JurkatHCV-1b as HCV-producing cultures were used in further experiments for the $\mathrm{ED}_{50}$ assessment.

To evaluate the neoflazidum cytotoxicity concentration $\left(\mathrm{CC}_{50}\right)$, the RHNN cells were taken. The range of neoflazidum concentrations was from 186 to $4.6 \mu \mathrm{g} / \mathrm{ml}$. Every dilution was analyzed in 10 replicates, the results being presented in the Table2.

As estimated in our studies, the cytodestructive cell changes were found for the concentrations of 186,93 and $47 \mu \mathrm{g} / \mathrm{ml}$, the neoflazidum $\mathrm{CC}_{50}$ value was shown for the concentration of $37.2 \mu \mathrm{g} / \mathrm{ml}$.

To evaluate the $\mathrm{ED}_{50}$, the neoflazidum preparation was put into the virus-producing JurkatHCV-3a and JurkatHCV-1b cultures in doses: 18.6, 9.3, 4.6, and $2.3 \mu \mathrm{g} / \mathrm{ml}$ and incubated at $37^{\circ} \mathrm{C}$. On the $5^{\text {th }}$ day of cultivation the virus reproduction was determined by the PCR method, the quantity of HCV genomeequivalents being a reproduction marker (Table 3 ).

The results obtained for neoflazidum with the JurkatHCV-3a and JurkatHCV-1b cultures show the virus load-decreasing effects to be quite different: it
Table 1. Results [of] HCV load in transfected cells Jurkat for different HCV types

\begin{tabular}{|c|c|c|c|c|}
\hline \multirow{2}{*}{$\begin{array}{c}\text { Passage } \\
\text { following } \\
\text { transfection }\end{array}$} & \multicolumn{4}{|c|}{$\begin{array}{c}\text { HCV load in transfected cells (genome/ } \\
\text { equivalents) for different HCV types }\end{array}$} \\
\cline { 2 - 5 } & 1 & $2-3 \mathrm{a}$ & 3 & $4-1 \mathrm{~b}$ \\
\hline $2^{\text {nd }}$ passage & 2537 & 4485 & 2512 & 13598 \\
$5^{\text {th }}$ passage & 3150 & 5400 & 3120 & 14100 \\
\hline
\end{tabular}

Table 2. Evaluation of the neoflazidum $\mathbf{C C}_{\mathbf{5 0}}$

\begin{tabular}{|l|c|c|c|c|c|c|c|}
\hline \multirow{3}{*}{ Preparation } & \multicolumn{7}{|c|}{ Concentration of preparation $(\mu \mathrm{g} / \mathrm{ml})$} \\
\cline { 2 - 8 } & 186 & 93 & 47 & 37.2 & 18.6 & 9.3 & 4.6 \\
\cline { 2 - 8 } & \multicolumn{7}{|c|}{ Cytodestructive changes } \\
\hline $\begin{array}{l}\text { neoflazi- } \\
\text { dum }\end{array}$ & $10 / 10$ & $10 / 10$ & $10 / 10$ & $0 / 10$ & $0 / 10$ & $0 / 10$ & $0 / 10$ \\
\hline
\end{tabular}

Table 3. Neoflazidum $\mathbf{E D}_{\mathbf{5 0}}$ for the $\mathrm{HCV}$

\begin{tabular}{|c|c|c|c|c|}
\hline \multirow[b]{2}{*}{$\begin{array}{l}\text { Preparation } \\
\text { concentra- } \\
\text { tion, } \mu \mathrm{g} / \mathrm{ml}\end{array}$} & \multicolumn{2}{|c|}{$\mathrm{HCV} 3 \mathrm{a}$} & \multicolumn{2}{|c|}{$\mathrm{HCV} 1 \mathrm{~b}$} \\
\hline & $\begin{array}{c}\text { virus load, } \\
\text { genome/ } \\
\text { equivalent }\end{array}$ & $\begin{array}{c}\text { inhibition, } \\
\%\end{array}$ & $\begin{array}{c}\text { virus load, } \\
\text { genome/ } \\
\text { equivalent }\end{array}$ & $\begin{array}{c}\text { inhibition, } \\
\%\end{array}$ \\
\hline 7.44 & 120 & 61 & 0 & 100 \\
\hline 3.72 & 0 & 100 & 100 & 54.4 \\
\hline 1.86 & 0 & 100 & 279 & 0 \\
\hline 0.93 & 56 & 81.8 & 305 & 0 \\
\hline 0.46 & 125 & 59.3 & 302 & 0 \\
\hline $\begin{array}{l}\text { Virus } \\
\text { control }\end{array}$ & 307 & & 219 & \\
\hline
\end{tabular}

Table 4. $\mathbf{C C}_{\mathbf{5 0}}, \mathbf{E D}_{\mathbf{5 0}}$, and SI for neoflazidum in Jurkat ${ }^{\mathrm{HCV}-3 a}$ and Jurkat ${ }^{H C V-1 b}$ cultures

\begin{tabular}{|l|c|c|c|}
\hline Genotype HCV & $\mathrm{CC}_{50}, \mu \mathrm{g} / \mathrm{ml}$ & $\mathrm{ED}_{50}, \mu \mathrm{g} / \mathrm{ml}$ & SI \\
\hline Jurkat $^{H C V-3 a}$ & 37.2 & 0.46 & 80.8 \\
Jurkat $^{H C V-1 b}$ & 37.2 & 3.72 & 10.0 \\
\hline
\end{tabular}

Table 5. Interferon level in organs of mice treated with the neoflazidum

\begin{tabular}{|c|c|c|c|c|c|c|c|c|}
\hline \multirow{4}{*}{$\begin{array}{l}\text { Organs } \\
\text { studied }\end{array}$} & \multicolumn{8}{|c|}{ IFN activity $(\mathrm{U} / \mathrm{ml})$ following injections of : } \\
\hline & \multicolumn{6}{|c|}{ the neoflazidum in doses: } & \multirow{3}{*}{$\underset{\Xi}{\Xi}$} & \multirow{3}{*}{$\begin{array}{l}1 \\
\frac{\lambda}{2} \\
\overline{0}\end{array}$} \\
\hline & \multicolumn{2}{|c|}{$37.2 \mu \mathrm{g} / \mathrm{kg}$} & \multicolumn{2}{|c|}{$7.4 \mu \mathrm{g} / \mathrm{kg}$} & \multicolumn{2}{|c|}{$3.72 \mu \mathrm{g} / \mathrm{kg}$} & & \\
\hline & $-\mathrm{pH}$ & $+\mathrm{pH}$ & $-\mathrm{pH}$ & $+\mathrm{pH}$ & $-\mathrm{pH}$ & $+\mathrm{pH}$ & & \\
\hline Blood & 320 & 0 & 160 & 0 & 320 & 20 & 2 & 1280 \\
\hline Spleen & 80 & 80 & 160 & 0 & 0 & 0 & 10 & 640 \\
\hline Liver & 40 & 40 & 80 & 80 & 160 & 160 & 10 & 640 \\
\hline Lungs & 320 & 0 & 160 & 0 & 320 & 0 & 10 & 320 \\
\hline Heart & 80 & 80 & 20 & 20 & 40 & 10 & 10 & 320 \\
\hline Kidneys & 160 & 160 & 20 & 20 & 320 & 0 & 10 & 320 \\
\hline
\end{tabular}


was $0.46 \mu \mathrm{g} / \mathrm{ml}$ in the first culture and eight times lower for the second one.

The results of the $\mathrm{CC}_{50}, \mathrm{ED}_{50}$, selectivity index (SI) evaluation are given in the Table 4.

The IFN-inducing neoflazidum activity in vivo was studied on the model of white non-inbred mice; the preparation $(0.1 \mathrm{ml})$ was injected into peritone$\mathrm{um}$, the concentrations being $37.2 \mu \mathrm{g} / \mathrm{kg}, 7.4 \mu \mathrm{g} / \mathrm{kg}$, and $3.72 \mu \mathrm{g} / \mathrm{kg}$. In $24 \mathrm{~h}$ the mice were killed by euthanasia; the IFN activities were determined in murine blood sera and in different animal organs according to a generally accepted approach - the inhibition of the CPE being caused by the vesicular stomatitis virus in homologous L929 cell cultures.

The IFN type was determined according to its acid sensibility. The supernatant fluids from the suspensions of organs as well as blood sera were divided in two samples. The fluid $\mathrm{pH}$ of one sample was adjusted to 2.0 using $4 \mathrm{~N} \mathrm{HCl}$ solution and kept the sample at $4^{\circ} \mathrm{C}$ during $24 \mathrm{~h}$; the fluid $\mathrm{pH}$ value was then restored up to 7.2 with the aid of $4 \mathrm{~N} \mathrm{NaOH}$. The results of this experiment are given in the Table 5.

We analyzed the results of $\alpha$ - and $\gamma$-IFNs activities testing (taking into consideration such marker as their acid sensitivity) in different organs of mice treated by different neoflazidum doses. Notably, the neoflazidum was an active IFN inducer, the $\alpha$ - and $\gamma$-IFN induction being dose-dependent. At a higher neoflazidum concentration $(37.2 \mu \mathrm{g} / \mathrm{kg}) \quad \alpha-$ and $\gamma$-IFN are induced, at lower concentrations, $7.4 \mu \mathrm{g} /$ $\mathrm{kg}$ and $3.72 \mu \mathrm{g} / \mathrm{kg}$, we detect mostly the $\gamma$-IFN induction. Interestingly, the blood sera and lung tissue contain $\gamma$-IFN without any dose-dependence.

\section{The neoflazidum effect on the in vitro $R N A$ synthesis in the transcription system RNAP T7}

The transcription is a key process for cell functioning and reproduction being simultaneously among the most important targets of antiviral and antimicrobial therapy. The organic compounds which are able to modify the transcription process are used as potential drugs - the inhibitors of viral and bacterial reproduction [9].

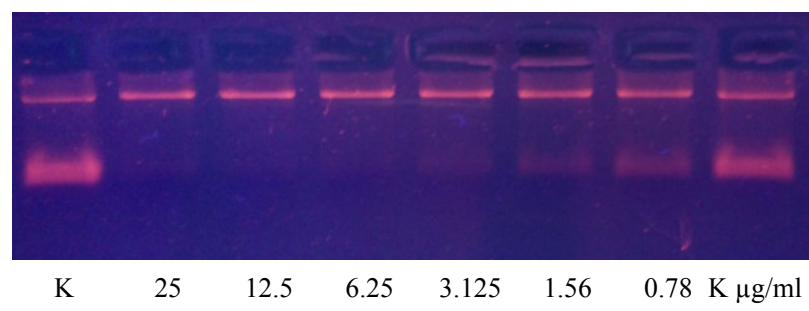

Fig. 1. Inhibition effect of neoflazidum $(25,12.5,6.25,3.125$, 1.56 , and $0.78 \mu \mathrm{g} / \mathrm{ml}$ ) on the RNA synthesis. $\mathrm{IC}_{50}=0.78 \mu \mathrm{g} / \mathrm{ml}$.

3D-structures of different DNA- and RNApolymerases are known to possess a high degree of similarity as well as to contain the same structural domains and conservative motifs necessary for the elongation of nucleic acid chains. That is why we chose an easy-to-use and productive model, the RNAP T7 transcription system [13], for both selection of RNA synthesis inhibitors and detection of effective antimicrobial or antiviral drugs.primary investigation of the neoflazidum in the model system RNAP T7 was carried out with preparations of $25 \mu \mathrm{g} / \mathrm{ml}$ concentration. All substances tested block completely the RNA synthesis. Two-fold dilutions were made to understand the effect dependence on the drug concentration (Fig. 1).

The data obtained testify a high neoflazidum inhibitory effect on the RNA synthesis. The plant extract has been shown to be an active inhibitor for the transcriptio-nal complex $\underline{\mathrm{RNAP} T 7}$, its $\mathrm{IC}_{50}$ value being $0.78 \mu \mathrm{g} / \mathrm{ml}$.

\section{Conclusions}

The data concerning a new plant origin preparation, namely a new proteflazidum form - neoflazidum, show its cytotoxic concentration to be $37.2 \mu \mathrm{g} / \mathrm{ml}$. The effective neoflazidum dose $\left(\mathrm{ED}_{50}\right)$ found on the model of virus-producing transfected cells Jurkat is $0.46 \mu \mathrm{g} / \mathrm{ml}$ for the HCV type 3 , being, however, eight times higher $(3.72 \mu \mathrm{g} / \mathrm{ml})$ for the HCV type $1 \mathrm{~b}$; it is a cause of a lower proteflazidum efficacy of the therapy of the hepatitis $C$ type $1 b$.

It has been demonstrated that the neoflazidum antiviral effect is realized through the RNA synthesis inhibition and the $\alpha$ - and $\gamma$-interferon induction. 
Study of antiviral activity of a new plant origin preparation neoflazidum on a model of the hepatitis c virus

\section{REFERENCES}

1. Porva YI, Rybalko SL, Kuklin FV et al. HCV-producing cell cultures obtained by transfection techniques. Symposium "HCV animal models and vaccine development" 1617.05.2013, Tallinn, Estonia:44.

2. L'vov DK. [Viral hepatitis]. Vopr Virusol. 2002;47(6):44-6.

3. van der Meer AJ, Wedemeyer H, Feld JJ, Dufour JF, Zeuzem $S$, Hansen BE, Janssen HL. Life expectancy in patients with chronic HCV infection and cirrhosis compared with a general population. JAMA. 2014;312(18):1927-8.

4. Gural AL, Marievskiy VF, Sergeyeva TA, Shaginyan VR, Ruban OM. Characteristics and trends of hepatitis' C epidemic process in Ukraine. Profilaktychna Meditsina. 2011;1 (13):9-18.

5. Kamili S, Drobeniuc J, Araujo AC, Hayden TM. Laboratory diagnostics for hepatitis $\mathrm{C}$ virus infection. Clin Infect Dis. 2012;55 Suppl 1:S43-8.

6. Chumak AA, Bieliayeva NV, et al. Viral hepatitis C: Problems of carrier state, therapy, and prevention. Zh Akad Med Nauk Ukr. 2000; 6(1):65-81.

7. Kwong AD, McNair L, Jacobson I, George S. Recent progress in the development of selected hepatitis $\mathrm{C}$ virus NS3.4A protease and NS5B polymerase inhibitors. Curr Opin Pharmacol. 2008;8(5):522-31.

8. Perni RB, Almquist SJ, Byrn RA, Chandorkar G, Chaturvedi PR, Courtney LF, Decker CJ, Dinehart K, Gates CA, Harbeson SL, Heiser A, Kalkeri G, Kolaczkowski E, Lin K, Luong YP, Rao BG, Taylor WP, Thomson JA, Tung RD, Wei Y, Kwong AD, Lin C. Preclinical profile of VX-950, a potent, selective, and orally bioavailable inhibitor of hepatitis C virus NS3-4A serine protease. Antimicrob Agents Chemother. 2006;50(3):899-909.

9. Maltais F, Jung YC, Chen M, Tanoury J, Perni RB, Mani N, Laitinen L, Huang H, Liao S, Gao H, Tsao H, BlockE, Ma C, Shawgo RS, Town C, Brummel CL, Howe D, Pazhanisamy S, Raybuck $S$, Namchuk M, Bennani YL. In vitro and in vivo isotope effects with hepatitis $C$ protease inhibitors: enhanced plasma exposure of deuterated telaprevir versus telaprevir in rats. J Med Chem. 2009;52(24):7993-8001.

10. Abonyi DO, Adikwu MU, Esimone CO, Ibezim EC. Plants as sources of antiviral agents. Afr J Biotechnol. 2009;8(17): 3989-94.

11. Al Ashaal HA, Farghaly AA, Abd El Aziz MM, Ali MA. Phytochemical investigation and medicinal evaluation of fixed oil of Balanites aegyptiaca fruits (Balantiaceae). J Ethnopharmacol. 2010;127(2):495-501.

12. Kaul TN, Middleton E Jr, Ogra PL. Antiviral effect of flavonoids on human viruses. J Med Virol. 1985;15(1):71-9.

13. Pat N 2252221. Bomberdelli E, Valenti P. Derivatives of flavones, xanthones, and coumarins and a pharmaceutical composition including them. Russian Federation Patent for the Invention 20.05.2005.
14. Lok AS, Gardiner DF, Lawitz E, Martorell C, Everson GT, Ghalib R, Reindollar R, Rustgi V, McPhee F, Wind-Rotolo M, Persson A, Zhu K, Dimitrova DI, Eley T, Guo T, Grasela DM, Pasquinelli $C$. Preliminary study of two antiviral agents for hepatitis C genotype 1. $N$ Engl $J$ Med. 2012;366(3):216-24.

15. Deriabin $P G, L^{\prime}$ vov $D K$. [A highly productive variant of the hepatitis $\mathrm{C}$ virus. Isolation, identification, characteristics]. Dokl Akad Nauk. 1998;358(5):685-7.

16. Attestation of Splitting Cell Lines - Substrates for Production and Control of Biological and Immunobiological Preparations. Methodical Recommendations. Moscow, 1989. $235 \mathrm{p}$.

17. Patent of a useful model N 40311. Rybalko SL, Porva YuI, Dyadiun ST. et al. Mode of hepatitis C viruses cultivation. 25.03.2009.

18. Avtsyn AP. A new neurogenous cell line RHNN-1 and its use in biotechnology. In the: Cultivation of Human and Animal Cells: Theses of the II All-Union Conference. Pushchino, 1985:75-6.

19. Avtsyn AP, Kondakova LI, Khalanskiu AS, Poliakova GP, Chudinovskaia $N V$. [A new cell line of rat gasserian ganglion neurinoma NGUK-1]. Tsitologiia. 1989;31(1):97102.

20. Shcherbinska AM, Dyachenko NS, Rybalko SL at al. Study of antiviral effect of potential medicinal drugs. In the: Preclinical Study of Drugs. Methodical Guidelines. Kyiv. 2001;371-95.

\section{Вивчення антивірусної активності препарату рослинного екстракту протефлазіду на моделі вірусу гепатиту $C$}

Ю. І. Порва, С. Л. Рибалко, Л. І. Пальчиковська, В. П. Атаманюк

Мета. Вивчення антивірусної активності нової форми рослинного екстракту Протефлазіду (РЕП) - Методи. Моделі продукуючої культури Jurkat кДНК ВГС. Результати. Одержані продукуючі ВГС культури клітин Jurkat методом трансфекції комплементарної ДНК до виділеної РНК ВГС від хворих гепатитом С за допомогою трансфекуючого реагента Turbofect. Цитотоксична доза (CD50) дорівнювала 37,2 мкг/мл, ефективна доза (ED50) в системі продукції вірусу гепатиту C 3а типу дорівнювала 23 мкг/мл, а в системі репродукції вірусу гепатиту C 1в типу - 18,6 мкг/мл. Тому індекс селективності для РЕП в системі продукуючих ВГС клітин За типу дорівнював 16,2, а для ВГС 1в типу - 2. Висновки. Механізм антивірусної дії РЕП відбувається за рахунок індукції $\alpha$ - та $\gamma$-інтерферону та інгібіції синтезу РНК в модельній системі РНКП Т7 - інгібуюча концентрація (IC50) - 0,78 мкг/мл.

Ключові слов а: antiviral activity, neoflazidum, hepatitis C virus, transfecting, interferons $\alpha$ - and $\gamma$-induction, model system RNAP T7 
Изучение противовирусной активности препарата растительного экстракта протефлазида на модели вируса гепатита $\mathrm{C}$

Ю. И. Порва, С. Л. Рибалко, Л. И. Пальчиковська, В. П. Атаманюк

Цель. Изученить антивирусную активности новой формы растительного экстракта Протефлазида (РЭП). Методы. Модель продуцируемого культуры Jurkat кДНК ВГС. Результаты. Полученные продуцирующие ВГС культуры клеток Jurkat методом трансфекции комплементарной ДНК к выделенной РНК ВГС от больных гепатитом С с помощью трансфекуючого реагента Turbofect. Цитотоксическое доза (CD50) равнялась 37,2 мкг / мл, эффективная доза (ED50) в системе продукции вируса гепатита С 3а типа равнялась 2 марта мкг / мл, а в системе репродукции вируса гепатита С 1в типа - 18,6 мкг / мл. Поэтому индекс селективности для РЭП в системе продуцирующих ВГС клеток За типа равен 16,2, а для ВГС 1в типа - 2. Выводы. Механизм антивирусного действия РЭП происходит за счет индукции $\alpha$ - и $\gamma$-интерферона и ингибирования синтеза РНК в модельной системе РНКП Т7 - ингибирующая концентрация (IC50) - 0,78 мкг / мл.

Ключевы е сл ов а: antiviral activity, neoflazidum, hepatitis C virus, transfecting, interferons $\alpha$ - and $\gamma$-induction, model system RNAP T7

Received 01.08.2015 